\title{
FAKTOR-FAKTOR YANG MEMPENGARUHI KOMITMEN ORGANISASI PADA PEGAWAI MILENIAL
}

\author{
Ery Muhayar Syafari \\ Retno Hanggarani Ninin, Fitri Ariyanti Abidin \\ ery18002@mail.unpad.ac.id
}

Fakultas Psikologi Universitas Padjadjaran

\begin{abstract}
This study aims to determine the factors that influence millenial employee commitment to work, in response to the notion that millenial organizational commitment tends to be less strong, while commitment is considered an important aspect in supporting organizational stability and performance. This study focuses on millenial employee who have survived working in one organization for relatively long time, carried out with a qualitative approach so that it is possible to explore factors that have the potential to influence their decision to stay in one organization. The result of this study will be useful for providing information for organizational management about the factors connected to work commitment of millenial workers. Respondents consisted of 6 people who are employees with an age range of 31 to 34 years old. They have worked at a telecommunications company for more than five years. Respondents consisted of 1 male dan 5 female, 3 of them are married and 3 are single. Through this research, obtained the knowledge that satisfactory income accompanied by various benefits, quite wide open opportunity for self-development, conducive work climate for innovation and creativity, and fair performance appraisals, those are factors that affect millenial employee's organizational commitment. The peculiarity of millenial employees compared to previous generations is that their commitment grows more due to the fulfillment of career deveopment and benefits for themselves, while other generation focus more on attachment for organizational development.
\end{abstract}

\section{Keywords: Organizational commitment, millenial worker, qualitative research}

Abstrak. Penelitian ini bertujuan untuk mengetahui faktor-faktor yang mempengaruhi komitmen pegawai milenial dalam bekerja, sebagai respon atas dugaan bahwa komitmen organisasi milenial cenderung kurang kuat, sementara komitmen dianggap sebagai aspek penting dalam menunjang stabilitas dan kinerja organisasi. Penelitian ini berfokus pada pegawai milenial yang bertahan bekerja di satu organisasi dalam waktu relatif lama, dilakukan dengan pendekatan kualitatif sehingga memungkinkan untuk mengeksplorasi faktor-faktor yang berpotensi mempengaruhi keputusan mereka untuk bertahan bekerja di satu organisasi. Hasil penelitian ini akan berguna untuk memberi informasi kepada manajemen organisasi tentang faktor yang terhubung dengan komitmen kerja pada pekerja milenial. Responden terdiri dari 6 orang yang merupakan pegawai dengan rentang usia 31 sampai 34 tahun. Keenamnya telah bekerja di sebuah perusahaan telekomunikasi lebih dari lima tahun. Responden terdiri dari 1 laki-laki dan 5 perempuan, 3 diantaranya menikah dan 3 lagi berstatus lajang. Melalui penelitian ini diperoleh pengetahuan bahwa penghasilan yang cukup memuaskan disertai berbagai tunjangan, ada kesempatan untuk pengembangan diri yang cukup terbuka luas, iklim kerja yang kondusif untuk munculnya 
inovasi dan kreativitas, dan penilaian kinerja yang adil merupakan faktor-faktor yang mempengaruhi komitmen pegawai milenial dalam bekerja. Kekhasan pegawai milenial dibanding dengan generasi sebelumnya adalah bahwa komitmen mereka tumbuh lebih karena alasan terpenuhinya pengembangan karir dan benefit untuk diri mereka sendiri, sedangkan generasi lain lebih berfokus pada keterikatan untuk pengembangan organisasi.

\section{Kata Kunci: Komitmen organisasi, pekerja milenial, penelitian kualitatif}

\section{Pengantar}

Pergantian generasi terjadi di berbagai bidang kehidupan, tidak terkecuali dalam konteks industri dan organisasi. Orang-orang yang menempati level tertentu di sebuah organisasi atau perusahaan lambat laun akan digantikan oleh generasi berikutnya. Pada masa sekarang, tempat-tempat bekerja menampung manusia dari generasi yang berbeda untuk bekerja bersama-sama. Adanya perbedaan generasi yang bekerja bersamasama dalam satu tempat kerja memunculkan perbedaan sifat-sifat kepribadian antar generasi tersebut dalam bekerja (Agrawal, 2017).

Generasi dalam angkatan kerja dibedakan menjadi beberapa kelompok, yakni generasi matures (lahir sebelum tahun 1945), baby boomers (lahir dari tahun 1945 - 1962), generasi X (1963 - 1982), generasi Y atau Milenial (1983 - 1997), dan generasi Z (lahir sekitar tahun 2000 dan setelahnya) (Yigit \& Aksay, 2015). Di Amerika Serikat, ada sekitar 73 juta milenial (PwC, 2011). Seperti pada setiap generasi sebelumnya, milenial kian tumbuh hingga memasuki fase yang disebut angkatan kerja produktif. Para milenial kini telah membentuk 25 persen dari angkatan kerja di AS. Pada tahun 2020, milenial diprediksi akan mampu membentuk 50 persen angkatan kerja secara global (PwC, 2011). Badan Pusat Statistik (BPS) tahun 2016 menyatakan bahwa generasi Milenial di Indonesia mencapai 40 persen dari total seluruh penduduk. Di tahun 2017, banyak survey menjelaskan bahwa angkatan kerja Milenial mencapai tidak kurang dari 30 persen dari seluruh angkatan kerja di Indonesia (Nindyati, 2017). Di tahun 2020, jumlahnya diprakirakan telah mencapai 50 hingga 60 persen. Dengan jumlah tersebut, estafet kepemimpinan di dunia kerja akan segera beralih ke tangan para milenial. Imbas dari kondisi ini beragam, mulai dari beralihnya budaya kerja, etos kerja, hingga berubahnya orientasi kerja para milenial dibandingkan generasi sebelumnya. Tantangan terbesar yang dihadapi oleh organisasi adalah adanya perubahan-perubahan pada perilaku dan sikap kerja para pegawai yang bekerja di dalamnya (Cheah, Chong, Yeo, \& Pee, 2016). Tantangan perubahan ini, terutama perubahan perilaku kerja yang akan mengarahkan pada perubahan budaya organisasi tentu bukan hal yang instan terjadi. Namun jika perubahan ini massif dan 
terus menerus terjadi, tentu pada saatnya nanti, budaya kerja milenial akan sangat menentukan wajah organisasi ke depan. Budaya organisasi atau perusahaan sangat persuasif dan mempengaruhi hampir keseluruhan aspek kehidupan organisasi (Simatupang, 2020).

Sejalan dengan meningkatnya persentase generasi milenial baik di dunia maupun di Indonesia, topik mengenai generasi milenial di tempat kerja telah mendorong begitu banyak diskusi (Stewart, Oliver, Cravens, \& Oishi, 2017). Milenial dikenal dengan generasi digital natives. Mereka lahir dalam era digital yang memungkinkan untuk mendapatkan informasi dari berbagai daerah dalam hitungan detik. Milenial terbiasa mendapatkan informasi dengan cepat, sehingga dalam kehidupan kerja, generasi ini termasuk yang tidak suka dengan kata-kata 'wait'. Dengan alasan ini milenial dikenal sebagai generasi yang tidak sabar. Karir bagi milenial bukanlah berada dalam satu perusahaan yang harus ditunggu pencapaiannya (Nindyati, 2017).

Hasil survey PricewaterhouseCoopers menyatakan bahwa sebanyak 38 persen milenial memilih untuk berpindah-pindah tempat kerja, 44 persen terbuka terhadap penawaran baru, dan hanya 18 persen yang berharap bekerja di satu perusahaan dalam rentang waktu lama (PwC, 2011). Sejalan dengan temuan PwC (2011), IDN Research Institute merilis hasil survey yang menyatakan bahwa 35 persen pegawai milenial di Indonesia berencana untuk bertahan dalam 2 sd 3 tahun bekerja di perusahaan yang sama, sedangkan hanya 10 persen yang berencana untuk bekerja di perusahaan yang sama lebih dari 10 tahun (Utomo, 2019). Hasil survey ini menyatakan fenomena rendahnya kesediaan para pekerja milenial untuk bertahan di sebuah organisasi dimana mereka bekerja. Tingkat turn over yang tinggi di kalangan mereka menimbulkan banyak kemungkinan masalah bagi kinerja organisasi ke depan. Hal yang paling jelas terdampak adalah investasi rekrutmen serta seleksi dan training yang akan meningkat.

Perilaku seringnya berpindah tempat kerja dari angkatan kerja milenial dapat menjadi indikasi bagi perilaku kurangnya komitmen dari karyawan milenial terhadap organisasi. Komitmen adalah keyakinan karyawan atas pilihannya untuk mendukung kesukseksan organisasi tempatnya bekerja dengan cara menunjukkan kesediaan untuk menetap (Nindyati, 2017). Komitmen organisasi dari para milenial sering dikeluhkan oleh manajemen di perusahaan dan organisasi. Para manajer di banyak perusahaan hampir mengungkapkan hal yang sama mengenai kebiasaan milenial yang suka untuk berpindahpindah tempat bekerja, disamping terdapat sejumlah persoalan lain menyangkut sikap terhadap otoritas dan pola komunikasi serta tingkat kedekatan yang berbeda. Seringkali, 
kebiasaan untuk mencari tawaran pekerjaan yang lebih baik dengan cara berpindah-pindah secara instan dinilai sebagai rendahnya komitmen organisasi (Glazer, Mahoney, \& Randall, 2019).

\section{Landasan Teori}

\section{Organizaional Commitment}

Komitmen merupakan aspek penting bagi berjalannya sebuah organisasi. Setiap perusahaan berupaya untuk mengembangkan komitmen para karyawannya terhadap organisasi dimana mereka bekerja. Disamping untuk mencapai stabilitas perusahaan, komitmen yang kuat dari para karyawannya pun akan meningkatkan kinerja perusahaan itu sendiri. Diyakini bahwa karyawan yang berkomitmen akan bekerja lebih keras dan melangkah lebih jauh untuk mencapai tujuan organisasi (Meyer, Allen, \& Gellatly, 1990). Pendapat Meyer \& and Allen (1990) ini sering digunakan oleh para peneliti di bidang Ilmu Perilaku Organisasi dan Ilmu Psikologi, bahwa komitmen organisasional sebagai sebuah kondisi psikologis yang mengkarakteristikkan hubungan karyawan dengan organisasi atau implikasinya yang mempengaruhi apakah karyawan akan tetap bertahan dalam organisasi atau tidak, yang teridentifikasi dalam tiga komponen yaitu:

1. Komitmen afektif (affective commitment), yaitu: keterlibatan emosional seseorang pada organisasinya berupa perasan cinta pada organisasi.

2. Komitmen kontinyu (continuance commitment), yaitu: persepsi seseorang atas biaya dan risiko dengan meninggalkan organisasi saat ini. Artinya, terdapat dua aspek pada komitmen kontinyu, yaitu: melibatkan pengorbanan pribadi apabila meninggalkan organisasi dan ketiadaan alternatif yang tersedia bagi orang tersebut.

3. Komitmen normatif (normative commitment), yaitu: sebuah dimensi moral yang didasarkan pada perasaan wajib dan tanggung jawab pada organisasi yang mempekerjakannya.

Penelitian-penelitian mengenai komitmen pada generasi milenial mendapatkan hasil bahwa generasi milenial kurang dalam sense of belongingness terhadap organisasi, lebih memiliki values pengembangan dirinya sendiri, dan memiliki mobilitas lebih tinggi sehingga lebih mudah bagi mereka untuk berpindah daripada menetap di sebuah organisasi (Ismail, Rahim, Lee \& Tahrir, 2016). Penelitian yang telah ada masih sangat sedikit yang mengungkapkan faktor-faktor yang melatarbelakangi perilaku berpindahpindah kerja dari milenial tersebut. Oleh karena itu, penelitian ini bertujuan untuk memberikan gambaran faktor-faktor yang berpengaruh pada komitmen organisasi pada generasi milenial. Dengan diketahuinya faktor- 
faktor tersebut, maka para manajer akan dapat menggunakan faktor-faktor tersebut sebagai cara untuk mempertahankan generasi milenial di organisasinya.

\section{Metode Penelitian}

Penelitian ini menggunakan metode kualitatif, dengan tujuan untuk mengeksplorasi faktor-faktor yang mempengaruhi komitmen pegawai milenial terhadap organisasi. Penelitian dilakukan terhadap pegawai dengan rentang tahun kelahiran antara tahun 1983 sd 1997 yang telah bekerja lebih dari lima tahun di PT. X. Generasi dengan rentang tahun kelahiran tersebut dinamai generasi $\mathrm{Y}$ atau milenial sesuai dengan pengelompokan yang merujuk pada Yigit \& Aksay (2015). Masa kerja lima tahun dipilih karena sesuai hasil survey IDN Research Institute tahun 2019, responden milenial dianggap telah cukup mampu bertahan untuk menetap di satu perusahaan jika telah lebih dari tiga tahun (Utomo, 2019). Jumlah responden sebanyak 6 orang, dengan komposisi terdiri dari 1 laki-laki dan 5 perempuan. Usia responden berkisar antara 31 sampai 34 tahun pada saat pengambilan data, dengan 3 orang lajang dan 3 orang telah menikah. Lama bekerja dari responden berkisar antara 5 sampai 15 tahun (di atas 5 tahun). Responden dalam penelitian ini diperoleh dari hasil rekomendasi manager di PT. X setelah terlebih dahulu peneliti mengajukan kriterianya.
Alat ukur yang digunakan adalah kuesioner terbuka yang disusun oleh penulis pertama. Pertanyaan dalam kuesioner meliputi data demografi seperti jenis kelamin, tanggal lahir, suku bangsa, dan lamanya bekerja. Pertanyaan terkait dengan faktor-faktor yang mempengaruhi komitmen organisasi pegawai milenial adalah: (1) pengalaman pertama diterima bekerja di PT. X; (2) harapan bekerja di PT. X; (3) Sejauh mana harapan-harapan itu terpenuhi hingga saat ini dan prediksi tercapainya harapan tersebut di masa yang akan datang; (4) berapa lama akan bekerja di PT. X dan apa yang membuat dapat bertahan lebih dari 5 tahun; (5) rencana karir dalam beberapa tahun ke depan; (6) faktor yang membuatnya bertahan yang ada di PT. X yang mungkin tidak ada di tempat lain; (7) bagaimana jika ada tawaran lebih baik dari perusahaan lain.

Sebelum pengambilan data dilakukan, kepada responden dijelaskan terlebih dahulu mengenai identitas peneliti, tujuan penelitian, kegunaan penelitian, serta jaminan kerahasiaan data yang diberikan. Setelah mendapatkan penjelasan tersebut, semua responden menyetujui untuk berpartisipasi dalam penelitian. Kepada responden diberikan tawaran untuk memilih cara menjawab lembar pertanyaan yang diberikan, yaitu melalui wawancara telepon atau dengan cara mengisi kuesioner secara tertulis. Seluruh responden memilih untuk mengisi form kuesioner secara 
tertulis. Pengisian kuesioner dilakukan pada form yang telah disiapkan oleh peneliti dengan disebar dalam format word melalui alamat email yang disetujui. Para responden menjawab setiap pertanyaan terbuka dengan menuliskan langsung pada form yang diberikan. Pengisian dilakukan oleh responden secara mandiri di luar jam kerja. Responden mengirimkan kembali form yang telah diisi melalui email kepada peneliti dalam rentang waktu 1 sampai dengan 3 hari.

Jawaban responden atas kuesioner ini adalah berupa kalimat-kalimat yang ditulis pada form yang dikembalikan kepada peneliti. Analisis data dilakukan dengan cara mengelompokkan jawaban-jawaban responden sesuai dengan tema-tema yang muncul dari jawaban subyek dalam kelompok kode: (1) harapan, (2) kondisi terpenuhi, (3) serta niat berpindah. Ketiga kode yang ditentukan ini mewakili seluruh pertanyaan yang diberikan di kuesioner yang berusaha menggali harapan sekaligus pencapaian saat pertama masuk PT. X, kondisi saat ini dan kondisi mendatang. Rancangan metode hingga analisis data dilakukan oleh penulis pertama atas persetujuan penulis kedua yang merupakan psikolog ahli untuk penelitian kualitatif.

\section{Hasil dan Pembahasan}

Hasil yang diperoleh dari pengambilan data pada penelitian ini adalah jawaban tertulis dari responden atas pertanyaan-pertanyaan dalam kuesioner terbuka. Bentuknya berupa kalimat-kalimat yang menjelaskan pengalaman subyektif setiap responden. Tahap pengolahan data dilakukan dengan terlebih dahulu mengelompokkan responden ke dalam kelompok responden yang sudah menikah sebanyak 3 orang dan lajang juga 3 orang. Selain jumlahnya yang berimbang, alasannya adalah bahwa diduga terdapat kaitan antara status perkawinan dengan komitmen pegawai. Individu yang telah menikah memiliki komitmen yang lebih tinggi terhadap organisasi mereka dibanding dengan yang single (Mathieu \& Zajac, 1990). Setelah membagi menjadi 2 kelompok berdasar data demografi status perkawinan, kolom berikutnya adalah membagi antara harapan mereka dengan pemenuhan yang diterimanya. Di dalam setiap kolom harapan maupun kondisi pemenuhan dituliskan kode berupa tema yang muncul dari setiap kelompok status perkawinan. Kode-kode dibuat berdasarkan informasi yang disampaikan responden menyangkut faktor-faktor yang mendorongnya bekerja di PT. X pada kolom harapan, dan faktor yang mempertahankannya untuk bekerja di perusahaan ini disimpan pada kolom kondisi terpenuhi saat ini. Hasilnya dipaparkan pada tabel 1 . 
Tabel 1. Gambaran faktor-faktor yang mempengaruhi komitmen organisasi pegawai milenial di PT.X

\begin{tabular}{|c|c|c|}
\hline Kode & Menikah & Lajang \\
\hline Harapan & $\begin{array}{l}\text { Mendapatkan penghasilan, } \\
\text { jenjang karir yang jelas, } \\
\text { kesempatan belajar dan } \\
\text { mengaplikasikan ilmu, } \\
\text { kesejahteraan yang lebih } \\
\text { baik, status sosial yang } \\
\text { meningkat karena bekerja di } \\
\text { BUMN }\end{array}$ & $\begin{array}{l}\text { Kebanggaan untuk dapat } \\
\text { bekerja di BUMN, sehingga } \\
\text { dapat berkarya untuk } \\
\text { negeri, mencetak para } \\
\text { pemimpin negeri, masa } \\
\text { depan yang cerah, terjamin } \\
\text { secara finansial, dapat } \\
\text { mengaplikasikan ilmu }\end{array}$ \\
\hline Kondisi terpenuhi & $\begin{array}{l}\text { Penghasilan cukup, } \\
\text { mendapat kesempatan } \\
\text { pengembangan karir yang } \\
\text { adil, tunjangan } \\
\text { kesejahteraan dan kesehatan } \\
\text { yang terpenuhi, kemudahan } \\
\text { mengerjakan tugas dengan } \\
\text { dukungan tools dan } \\
\text { teknologi, pengelolaan } \\
\text { modern, flexi time, dan } \\
\text { kenyamanan dalam tempat } \\
\text { ibadah, rekreasi dan tempat } \\
\text { berolahraga }\end{array}$ & $\begin{array}{l}\text { Mendapatkan lingkungan } \\
\text { kerja yang kondusif, } \\
\text { manajemen tidak feodal, } \\
\text { dapat memperoleh } \\
\text { penghasilan yang baik, } \\
\text { memperoleh kesempatan } \\
\text { belajar, dapat menjalankan } \\
\text { pekerjaan dengan berbasis } \\
\text { teknologi IT, mendapatkan } \\
\text { kesempatan untuk bekerja } \\
\text { di luar negeri dalam } \\
\text { program global talent, } \\
\text { menjalani pekerjaan dalam } \\
\text { lingkungan smart office }\end{array}$ \\
\hline
\end{tabular}

Niat berpindah

Tidak akan berpindah

Tidak akan berpindah

Tabel 1 menjelaskan bahwa secara garis besar tidak ada perbedaan harapan dalam mengawali masa kerja di PT. X antara kelompok menikah dengan kelompok lajang. Keduanya merinci faktor-faktor yang sama yang menjadi harapan kedua kelompok saat mengawali bekerja. Dari kedua kelompok dapat diungkap bahwa bekerja di BUMN merupakan impian atau keinginan diri mereka, bahkan keinginan orang tua mereka. Penjelasan akan dorongan untuk menjadi pegawai BUMN dijelaskan dengan faktor berikutnya, yakni jenjang karir yang jelas serta penghasilan yang akan tercukupi. Disamping itu, ada faktor kebanggaan yang lebih mencirikan meningkatnya status sosial manakala mereka bekerja di BUMN. Pada faktor lain, kedua kelompok menunjukkan adanya harapan ideal, yakni ingin mengaplikasikan ilmu yang telah mereka dapatkan dari pendidikan. 
Pada kode kondisi terpenuhi, kedua kelompok menunjukkan faktor-faktor yang juga pada umumnya hampir sama. Beberapa faktor yang muncul adalah penghasilan yang cukup, bahkan memuaskan, serta diperolehnya tunjangan-tunjangan yang dibutuhkan, misalnya tunjangan kesehatan dan pendidikan. Kesempatan yang diberikan untuk berkembang pun muncul di kedua kelompok status perkawinan ini, tidak sekadar pengembangan yang menunjang keahlian dalam bekerja, bahkan pengembangan yang lebih luas lagi berupa kesempatan bekerja di luar negeri dalam program global talent. Iklim kerja yang kondusif untuk terciptanya inovasi dan kreativitas dengan konsep smart office pun muncul menjadi faktor yang menguatkan mereka bertahan di PT. X. Orientasi pada pengembangan teknologi khususnya teknologi informasi menjadi bagian yang tidak luput menjadi faktor yang disebutkan responden milenial dalam penelitian ini. Dengan demikian, kemudahan kerja dapat tercapai sehingga hasilnya menjadi lebih cepat dan lebih efektif. Penilaian kinerja dan peluang pengembangan karir pun diperoleh dengan kesempatan yang sama dan adil, dalam arti tidak dibeda-bedakan berdasarkan jenis kelamin, tingkat pendidikan, atau faktor-faktor lain yang tidak relevan.

Hal yang cukup menarik dari temuan penelitian ini adalah bahwa apa yang dapat dipenuhi dan telah diterima pegawai milenial di PT. X ternyata jauh lebih besar jika dibandingkan dengan harapan awal mereka ketika diterima bekerja, bahkan budaya perusahaan yang disangkakan diawal akan bernuansa 'feodal' menurut salah satu responden, ternyata tidak demikian kondisi yang dirasakannya saat ini. Beberapa responden menyebutkan tentang budaya kekeluargaan di PT. X. Oleh karena itu, responden milenial dalam penelitian ini menyatakan bahwa mereka tidak akan berpindah ke lain organisasi, bahkan ada yang menyatakan tidak terpikir sama sekali untuk bekerja di tempat lain walau kompensasi lebih besar, karena budaya perusahaan di organisasi baru belum tentu senyaman dan sebaik di PT. $\mathrm{X}$.

Hasil penelitian ini pun menunjukkan bahwa salah satu faktor yang menguatkan komitmen mereka untuk bertahan di PT.X adalah karena adanya pemberian kesempatan yang sama bagi semua pihak untuk berkembang. Kesempatan yang sama akan menandai adanya keadilan yang diberikan perusahaan. Ia tidak membedakan dari segi lain yang tidak relevan dengan kinerja. PT. X memberikan kesempatan yang sama bagi semua karyawan.

Pada bagian akhir dari alat ukur kuesioner terbuka ditanyakan kepada responden tentang kemungkinan untuk meninggalkan PT. X jika ada perusahaan lain yang memberikan penawaran lebih baik. 
Semua responden menjawab bahwa tidak akan meninggalkan PT. X, walau ada 2 dari 6 yang menyatakannya dengan syarat, yakni selama PT. X sehat dan selama tidak ada yang memberikan penawaran lebih baik dalam segala aspeknya. Sisanya bahkan tidak terpikir sama sekali untuk pindah ke lain perusahaan, karena sudah merasa terpenuhi hal-hal yang dibutuhkan.

\section{Diskusi}

Penelitian ini bertujuan untuk memberikan gambaran faktor-faktor yang berpengaruh pada komitmen organisasi pada generasi milenial. Hasilnya menunjukkan bahwa komitmen organisasi pada generasi milenial memiliki kekhasan dari generasigenerasi lain. Faktor-faktor yang muncul lebih banyak berfokus pada pengembangan karir dan benefit yang diterima untuk dirinya, sedangkan generasi lain lebih berfokus pada pengembangan organisasi. Hal ini sejalan dengan penelitian yang dilakukan oleh Nindyati (2017). Jika dikaitkan dengan komponen komitmen dari Meyer et al., (1990), maka komponen continuance commitment menjadi ciri yang lebih menonjol dari generasi milenial dengan melihat pertimbanganpertimbangan beratnya meninggalkan keuntungan yang sudah diterimanya selama ini di sebuah organisasi menyebabkan mereka memilih untuk menetap.
Beberapa keuntungan yang terungkap dalam penelitian ini adalah kesempatan untuk berkembang yang cukup terbuka, bahkan perusahaan membuka kesempatan untuk meningkatkan pengetahuan dan keahlian, tidak hanya di dalam internal perusahaan melainkan juga untuk belajar di luar negeri. Bagi pegawai milenial, orientasi pada pengembangan diri dan kesempatan untuk mempelajari kemampuan dan keahlian baru lebih penting dibanding penghargaan finansial (PwC, 2011). Faktor kesempatan untuk promosi secara adil pun merupakan temuan penting dalam penelitian ini. Faktor adanya kesetaraan dan keadilan ini sebenarnya telah dibuktikan dalam penelitian sebelumnya tentang apa yang dinamakan sebagai distributive justice. Distributive Justice merujuk pada persepsi individu mengenai keadilan dan keseimbangan dalam jumlah dan jenis penghargaan yang diberikan organisasi kepada para anggotanya (Folger \& Konovsky, 2018). Jika individu merasa bahwa penghargaan yang diterimanya seimbang atau adil, maka akan muncul Distributive Justice. Distributive Justice ini berkorelasi positif dengan organizational commitment. Individu akan menunjukkan komitmen yang lebih besar terhadap organisasi yang dalam pandangan mereka telah memberikan penghargaan yang adil dan seimbang untuk prestasi kerja mereka (McFarlin \& Sweeney, 2018). Untuk faktor terkait harapan promosi tidak banyak berbeda 
dengan generasi sebelumnya. Milenial juga mengharapkan kenaikan jenjang karir yang cepat (PwC, 2011). Benefit berupa kedudukan atau status yang baik muncul dalam jawabanjawaban dari responden di penelitian ini, bahkan terungkap bahwa orang tua mereka mendorong untuk bekerja di perusahaan yang berstatus BUMN seperti PT. X. Hal ini sejalan dengan survey PwC (2011) bahwa brand perusahaan yang mereka kagumi menarik dan menjadi pertimbangan bagi para milenial untuk masuk di dalamnya. Faktor berikutnya adalah kesejahteraan yang ditawarkan oleh perusahaan seperti PT. X menjadi faktor yang membuat milenial dalam responden penelitian ini memutuskan untuk menetap lebih dari 5 tahun. Kesejahteraan kerja dan kehidupan mapan juga menjadi hal yang sejatinya didamba milenial. Sebanyak 95 persen responden mengatakan keseimbangan kerja dan hidup penting bagi mereka (PwC, 2011).

Diskusi mengenai milenial di tempat kerja akan terus bergulir dalam beberapa waktu ke depan. Terutama karena sebuah keniscayaan bahwa generasi akan berganti dan milenial ini yang akan menentukan wajah organisasi dan perusahaan di masa mendatang. Menurut survey IDN, milenial akan memegang peranan penting pada periode 2025 sampai 2030 (Utomo, 2019). Bentuk komitmen dalam konsep masa lalu, dimana memandang bahwa bertahan dalam satu organisasi adalah satu-satunya yang menunjukkan komitmen terhadap perusahaan, maka dengan kenyataan yang dihadapi saat ini dengan fenomena milenial nampak harus membuka mata bahwa terdapat komitmen dalam bentuk lain yang lebih penting dan lebih menunjang pencapaian kinerja perusahaan atau organisasi.

Karakteristik milenial dalam bekerja yang menuntut fleksibilitas dalam waktu bahkan prosedur tidak mesti dipandang sebagai hal buruk, selama kontribusi mereka dapat dibuktikan bahkan lebih baik dibanding dengan generasi yang lain. Banyak fenomena dimana para pekerja sekarang tidak berada pada tempat atau kantor yang tetap dan kaku. Mereka menjalani tugas dalam keadaan mobile, namun target pekerjaannya dapat dicapai.

Keputusan untuk menanamkan komitmen bertahan di satu perusahaan ada kaitannya dengan konsekwensi berikutnya, yakni menurunnya niat untuk berhenti atau keluar dari perusahaan tersebut. Penelitian sebelumnya menemukan bahwa semakin kuat komitmen organisasi individu maka semakin kecil niat untuk berhenti (Kumar et al., 2012).

\section{Kesimpulan}

Penelitian ini menghasilkan kesimpulan bahwa faktor-faktor yang dapat mempengaruhi komitmen milenial terhadap organsiasi mereka adalah karena penghasilan yang cukup, bahkan memuaskan, serta 
diperolehnya tunjangan-tunjangan yang dibutuhkan, adanya kesempatan untuk berkembang yang terbuka, iklim kerja yang kondusif untuk terciptanya inovasi dan kreativitas dengan kelengkapan kerja yang berorientasi pada teknologi tinggi, penilaian kinerja dan peluang pengembangan karir yang sama dan adil. Dengan demikian, manajemen organisasi yang ingin mempertahankan pegawai milanial perlu memperhatikan faktorfaktor di atas.

\section{Kepustakaan}

Agrawal, S. (2017). Personality traits and organisational commitment of Gen X and Gen Y employee. Journal of Organisation \& Human Behaviour.

Cheah, C. S., Chong, V. S. W., Yeo, S. F., \& Pee, K. (2016). An Empirical Study on Factors Affecting Organizational Commitment among Generation X. Procedia - Social and Behavioral Sciences. https://doi.org/10.1016/j.sbspro.2016.05. 002

Folger, R., \& Konovsky, M. A. (2018). Effects of Procedural and Distributive Justice on Reactions to Pay Raise Decisions. Academy of Management Journal. https://doi.org/10.5465/256422

Glazer, S., Mahoney, A. C., \& Randall, Y. (2019). Employee development's role in organizational commitment: a preliminary investigation comparing generation $\mathrm{X}$ and millennial employees. Industrial and Commercial Training. https://doi.org/10.1108/ICT-07-20180061

Ismail, M., Rahim, A. N. A., Lee, K. H., \& Tahrir, N. F. M. (2016). Culturl values and career goal of gen-X and gen- $Y$ employees: Evidence from selected Malaysian companies. Organizations and Markets in Emerging Economies. https://doi.org/10.15388/omee.2016.7.2. 14207

Kumar et al. (2012). A Study on Turnover Intention in Fast Food Industry: Employees' Fit to the Organizational Culture and the Important of their Commitment. International Journal of Academic Research in Business and Social Sciences.

Mathieu, J. E., \& Zajac, D. M. (1990). A Review and meta-analysis of the antecedents, correlates, and consequences of organizational commitment. Psychological Bulletin. https://doi.org/10.1037/00332909.108.2.171

McFarlin, D. B., \& Sweeney, P. D. (2018). Research notes. Distributive and procedural justice as predictors of satisfaction with personal and organizational outcomes. Academy of Management Journal. https://doi.org/10.5465/256489

Meyer, J. P., Allen, N. J., \& Gellatly, I. R. (1990). Affective and Continuance commitment to the organization: evaluation of measures and analysis of concurrent and time-lagged relations. Journal of Applied Psychology. https://doi.org/10.1037/00219010.75.6.710

Nindyati, A. D. (2017). Pemaknaan loyalitas karyawan pada generasi $\mathrm{X}$ dan generasi $\mathrm{Y}$ (Studi Pada Karyawan Di Indonesia). Journal of Psychological Science and Profession. https://doi.org/10.24198/jpsp.v1i3.15230

PwC. (2011). Millennials at work: Reshaping the workplace. In $P W C$. https://doi.org/10.1590/S003489102005000400004 
Simatupang. M. (2020). Budaya organisasi sebagai variabel prediktor terhadap organizational citizenship behavior pada karyawan koperasi. Psychopedia Jurnal Psikologi Universitas Buana Perjuangan Karawang.

https://doi.org/10.36805/psychopedia.v5i 1.1001

Stewart, J. S., Oliver, E. G., Cravens, K. S., \& Oishi, S. (2017). Managing millennials: Embracing generational differences. Business Horizons. https://doi.org/10.1016/j.bushor.2016.08. 011

Utomo, W. P. (2019). Indonesia Millennial Report. In IDN Research Institute.

Yigit, S., \& Aksay, K. (2015). A comparison between generation $\mathrm{x}$ and generation $\mathrm{y}$ in terms of individual innovativeness behavior: the case of Turkish Health professionals. International Journal of Business Administration. https://doi.org/10.5430/ijba.v6n2p106 